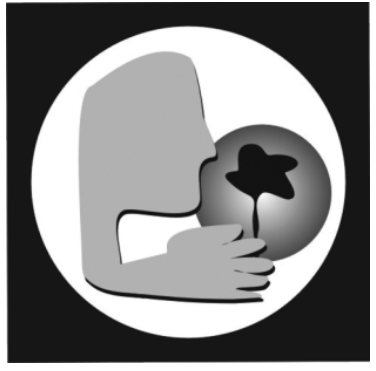

Sustentabilidade e $m$ Debate

Recebido em 15.12.2009

Aceito em 07.04.2010

\section{Unidades de Conservação de Santa Catarina}

\author{
Mariana Vitali ${ }^{1}$, Vivian Mara Uhlig ${ }^{2}$
}

${ }^{1}$ Bióloga, M.Sc. Fundação Nacional de Saúde - Funasa. mariana_vitali@yahoo.com.br.

${ }^{2}$ Bióloga, M.Sc., Instituto Chico Mendes de Conservação da Biodiversidade - ICMBio.vivianuhlig@hotmail.com.
Palavras-Chave:

Conservação

Unidades de Conservação Estaduais

Santa Catarina

Key-words:

Conservation

Protected Areas

Santa Catarina

\section{RESUMO}

Este estudo tem como foco as Unidades de Conservação Estaduais de Santa Catarina. Os objetivos são compreender a importância e a motivação da criação destas áreas protegidas; analisar seus processos de implementação; e sua contribuição no cenário conservacionista para a manutenção das funções ecológicas e preservação do patrimônio natural do estado. A metodologia empregada para coleta dos dados baseou-se em levantamento bibliográfico de dados secundários, entrevistas com a Fundação de Meio Ambiente (FATMA) e consulta a banco de dados do Instituto Chico Mendes de Conservação da Biodiversidade (ICMBio). Os resultados encontrados revelam a existência de um arcabouço legal mínimo para fortalecimento do sistema estadual de unidades de conservação. No entanto, demonstra que nem todas as UCs criadas possuem suporte e condições adequadas no sentido de atender os objetivos que justificaram a sua criação, assinalando fragilidades que demandam a revisão e a incorporação de ações para que as políticas públicas que tratam da conservação de áreas protegidas se tornem mais efetivas.

\section{ABSTRACT}

This study focuses on the conservation areas of Santa Catarina's State. The goals are to understand the importance and motivation for the creation of the protected areas, analyze their implementation processes, and their contribution to the conservation scenario for the maintenance of ecological functions and conservation of the State's natural resources. The methodology used for data collection was based on literature review of secondary's references sources, interviews with the Environmental Foundation (FATMA) and query the database from the Chico Mendes Institute for Biodiversity Conservation (ICMBio). The results reveal the existence of a minimum legal framework for strengthening the protected areas system studied. However, it shows that not all conservation areas have created the appropriate conditions and support to meet the objectives that justified its creation, pointing out weaknesses that require review and incorporation of actions to become public policies of protected areas more effective. 


\section{Unidades de Conservação de Santa Catarina}

\section{Introdução}

Uma variedade de ecossistemas característicos da zona costeira e marinha, assim como remanescentes de ecossistemas florestais da Floresta Atlântica estão representados no Estado de Santa Catarina (IBGE, 2007).

O Estado Catarinense possui uma extensão territorial de $95.985 \mathrm{~km}^{2}$, sendo que, aproximadamente, $85 \%$ destes estavam originalmente cobertos por Floresta Atlântica (PROCHNOW, 2008).

O Bioma Mata Atlântica, caracterizado por um mosaico diversificado de ecossistemas, apresenta estruturas e composições florísticas diferenciadas, decorrentes das variações de solo, relevo e características climáticas diversas em sua ampla área de ocorrência no Brasil. Atualmente, restam 7,3\% da cobertura vegetal original deste Bioma no país, sendo Santa Catarina o terceiro Estado com maior área de remanescentes, resguardando, em 1995, cerca de 1.666.241ha ou $17,41 \%$ da área original do bioma no Estado (FATMA, 2004).

No Estado de SC o bioma abrange três ecossistemas florestais, sendo eles: a) Floresta ombrófila densa; b) Floresta ombrófila mista e c) Floresta estacional decidual (PROCHNOW, 2008).

A floresta ombrófila densa ocupa predominantemente o litoral e se estende até as serras Geral, do Mar e do Espigão. Inicialmente sua área de extensão era de aproximadamente $31.611 \mathrm{~km}^{2}$ ou $32,9 \%$ do território catarinense, considerando seus ecossistemas associados (manguezais e restingas). De sua área original restam aproximadamente $7.000 \mathrm{~km}^{2}$, distribuídos em remanescentes florestais primários ou em estágio avançado de regeneração. A floresta ombrófila mista cobria $40.807 \mathrm{~km}^{2}$, ou seja, $42,5 \%$ do território de SC compondo, assim, a cobertura florestal predominante no Estado. A floresta estacional decidual ocorre nas altitudes mais baixas do vale do rio Uruguai e de seus afluentes, ocupava $9.196 \mathrm{~km}^{2}$, perfazendo 9,6\% da cobertura florestal de Santa Catarina. Associada a ela, existem os campos nativos e as florestas nebulares, cujas áreas originais estimadas eram $14,4 \%\left(13.794 \mathrm{~km}^{2}\right)$ e $0,6 \%\left(575 \mathrm{~km}^{2}\right)$, respectivamente (FATMA, 2004).
Considerando a diversidade e riqueza do patrimônio natural da região; a forma de ocupação territorial; a estrutura fundiária, na qual predomina a pequena propriedade familiar; e, em particular, a variedade na composição étnica da população foi instalado um modelo próprio de exploração sócio-econômica do território, em que se observou uma crescente participação no setor de serviços, particularmente, na exploração do turismo e no desenvolvimento tecnológico (SDM, 1997).

O processo de ocupação do espaço geográfico em Santa Catarina condicionou intensa pressão sobre os recursos naturais restando, atualmente, fragmentos reduzidos e isolados de biomas e ecossistemas associados.

Nesse sentido, o presente trabalho busca apresentar e analisar as principais áreas estaduais protegidas de Santa Catarina, a fim de compreender a importância e motivação de criação das unidades de conservação (UCs), analisar o processo de implementação, bem como sua contribuição para a manutenção das funções ecológicas e conservação do patrimônio natural do Estado.

A metodologia empregada para coleta dos dados apresentados neste trabalho baseou-se no levantamento bibliográfico de dados secundários, em ligações telefônicas para o Núcleo de UCs da Fundação de Meio Ambiente de Santa Catarina (FATMA), bem como consultas a banco de dados disponíveis do Instituto Chico Mendes de Conservação da Biodiversidade (ICMBio).

\section{Unidades de Conservação Estaduais}

$\mathrm{O}$ crescente processo de degradação dos ambientes naturais gerou iniciativas em escala mundial para criação de áreas legalmente protegidas, por legislação específica e com regime de uso voltado à conservação. No passado, a escolha de uma área protegida se dava com base nos aspectos cênicos, potencialidades de lazer e na disponibilidade de terra. Várias unidades de conservação no mundo foram criadas a partir desta perspectiva. Com o avanço do conhecimento sobre a diversidade biológica e com a fundamentação teórica da biologia da conservação, novos critérios passaram a ser considerados e relevantes. Atualmente, as 


\section{Sustentabilidade em Debate}

metodologias utilizadas para seleção de áreas prioritárias para conservação, baseiam-se na distribuição de espécies ou se fundamentam na distribuição de ecossistemas (DRUMMOND et al., 2006).

- Segundo o IBAMA (2007), a escolha de uma área com aptidão para constituir uma unidade de conservação é efetuada com base na análise de diversos fatores, dentre eles:

- O estado de conservação da área - uma UC deve possuir grande parte de sua área coberta pela vegetação natural da região, com pouca ou quase nenhuma modificação antrópica;

- A presença de espécies raras, endêmicas ou ameaçadas de extinção. Estas espécies são possivelmente as que desapareceriam primeiro, caso as modificações em seu habitat continuassem. Assim, elas devem ser consideradas como prioritárias para a conservação;

- A representatividade da região ecológica natural;

- A complementaridade ao atual Sistema de Unidades de Conservação (SNUC). Esta medida indica como a UC proposta contribuirá para a conservação de ecossistemas ou paisagens ainda não protegidas dentro de uma determinada região ecológica natural;

- A diversidade de ecossistemas e de espécies;

- A área disponível para implantação de uma unidade de conservação;

- O valor histórico, cultural, antropológico e beleza cênica da região;

- O grau das pressões humanas sobre a área;

- A situação fundiária ou viabilidade de regularização fundiária.

As iniciativas para a criação das primeiras unidades de conservação surgiram já no século XIX, tendo como marco a criação, nos Estados Unidos, do Parque Nacional de Yellowstone, em 1872. No Brasil, iniciativas esparsas começaram a partir da década de 1930, com a criação do Parque Nacional de Itatiaia em 1937 no Rio de Janeiro (DRUMMOND et al., 2006). Em Santa Catarina, a primeira unidade de conservação estadual foi criada em 1975, o Parque Estadual da Serra do Tabuleiro, a maior UC do
Estado, abrangendo parte do território de nove municípios (FATMA, 2007).

Na tabela a seguir (tabela 1) são listados os principais dispositivos legais referentes às unidades de conservação de Santa Catarina. Por esta tabela, podese perceber o desenvolvimento dos atos de criação de UCs e leis de proteção do meio ambiente seguindo uma linha cronológica. Inicia-se nos tempos atuais até 1975, ano de criação da primeira UC Estadual de Santa Catarina.

De acordo com o Sistema Estadual de Conservação da Natureza de Santa Catarina as UCs são divididas segundo sua categoria de uso, podendo ser de: a) USO INDIRETO: aquele que não envolve coleta, consumo, dano ou destruição dos recursos naturais; b) USO DIRETO: aquele que envolve coleta e uso, comercial ou não, dos recursos naturais (BRASIL, 2000).

A Diretoria de Proteção dos Ecossistemas da FATMA tem sob sua responsabilidade a gestão de 11 unidades de conservação ambientais: 7 na categoria de Parque, 1 Estação Ecológica e 3 na categoria de Reserva Biológica.

A Tabela 2 apresenta um quadro comparativo das 11 unidades de conservação administradas pela FATMA, seguida de uma descrição mais detalhada das principais características das UCs Estaduais do Estado de SC listadas.

$$
* * *
$$




\section{Unidades de Conservação de Santa Catarina}

Tabela 1 -Atos legais referentes às Unidades de conservação do Estado de Santa Catarina. (fonte: MP SC, 2007)

\begin{tabular}{|c|c|}
\hline ATOS LEGAIS & DISPOSIÇÕES \\
\hline $\begin{array}{l}\text { DECRETO ESTADUAL N }^{\circ} \\
308 / 2007\end{array}$ & $\begin{array}{l}\text { Define o Parque Florestal do Rio Vermelho como Parque } \\
\text { Estadual do Rio Vermelho e dá outras providências. }\end{array}$ \\
\hline LEI FEDER & $\begin{array}{l}\text { Dispõe sobre o plantio de organismos geneticamente } \\
\text { modificados em unidades de conservação; acrescenta } \\
\text { dispositivos à Lei } n^{\circ} 9.985 \text {, de } 18 \text { de julho de } 2000 \text {, e à } \\
\text { Lei } \mathrm{n}^{\circ} 11.105 \text {, de } 24 \text { de março de } 2005 \text {; revoga } \\
\text { dispositivo da Lei } \mathrm{n}^{\circ} 10.814 \text {, de } 15 \text { de dezembro de } 2003 \text {; } \\
\text { e dá outras providências. }\end{array}$ \\
\hline $\begin{array}{l}\text { DECRETO FEDERAL } \mathrm{N}^{\circ} \\
5.950 / 2006\end{array}$ & $\begin{array}{l}\text { Regulamenta o art. } 57-\text { A da Lei } n^{\circ} 9.985 \text {, de } 18 \text { de julho } \\
\text { de 2000, para estabelecer os limites para o plantio de } \\
\text { organismos geneticamente modificados nas áreas que } \\
\text { circundam as unidades de conservação. }\end{array}$ \\
\hline $\begin{array}{l}\text { MEDIDA PROVISÓRIA N }{ }^{\circ} \\
327 / 2006\end{array}$ & $\begin{array}{l}\text { Dispõe sobre o plantio de organismos geneticamente } \\
\text { modificados em unidades de conservação, acrescenta } \\
\text { dispositivos à Lei no } 9.985 \text {, de } 18 \text { de julho de } 2000 \text {, e dá } \\
\text { outras providências. }\end{array}$ \\
\hline
\end{tabular}

Convertida - LEI FEDERAL No. 11.460/2007, de 21 de março de 2007.

\begin{tabular}{|c|c|}
\hline $\begin{array}{l}\text { DECRETO FEDERAL } \mathrm{N}^{\circ} \text {. } \\
5.566 / 2005\end{array}$ & $\begin{array}{l}\text { Dá nova redação ao caput do art. } 31 \text { do Decreto } \mathrm{n}^{\circ} 4.340 \text {, } \\
\text { de } 22 \text { de agosto de } 2002 \text {, que regulamenta artigos da Lei } \\
\mathrm{n}^{\circ} 9.985 \text {, de } 18 \text { de julho de } 2000 \text {, que dispõe sobre o } \\
\text { Sistema Nacional de Unidades de Conservação da } \\
\text { Natureza-SNUC. }\end{array}$ \\
\hline 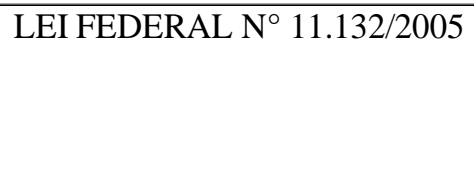 & $\begin{array}{l}\text { Acrescenta artigo à LEI FEDERAL } \mathrm{N}^{\circ} 9.985 \text {, de } 18 \text { de } \\
\text { julho de } 2000 \text {, que regulamenta o art. } 225, \S 1^{\circ} \text {, incisos I, } \\
\text { II, III e VII da Constituição Federal e institui o Sistema } \\
\text { Nacional de Unidades de Conservação da Natureza. }\end{array}$ \\
\hline $\begin{array}{l}\text { DECRETO ESTADUAL N }^{\circ} \\
797 / 2003 \\
\end{array}$ & $\begin{array}{l}\text { Cria o Parque Estadual Fritz Plaumann e dá outras } \\
\text { providências. }\end{array}$ \\
\hline $\begin{array}{l}\text { DECRETO ESTADUAL N }{ }^{\circ} \\
293 / 2003 \\
\end{array}$ & $\begin{array}{l}\text { Cria o Parque Estadual das Araucárias, e dá outras } \\
\text { providências. }\end{array}$ \\
\hline $\begin{array}{l}\text { DECRETO FEDERAL } \mathrm{N}^{\circ} \\
4.340 / 2002\end{array}$ & $\begin{array}{l}\text { Regulamenta artigos da Lei } \mathrm{n}^{\circ} 9.985 \text {, de } 18 \text { de julho de } \\
2000 \text {, que dispõe sobre o Sistema Nacional de Unidades } \\
\text { de Conservação da Natureza - SNUC, e dá outras } \\
\text { providências. }\end{array}$ \\
\hline $\begin{array}{l}\text { LEI ESTADUAL N }^{\circ} \\
11.986 / 2001\end{array}$ & $\begin{array}{l}\text { Institui o Sistema Estadual de Unidades de Conservação } \\
\text { da Natureza e adota outras providências. }\end{array}$ \\
\hline $\begin{array}{l}\text { LEI FEDERAL No. } \\
9.985 / 2000\end{array}$ & $\begin{array}{l}\text { Regulamenta o art. } 225, \S 1^{\circ} \text {, incisos I, II, III e VII da } \\
\text { Constituição Federal, institui o Sistema Nacional de } \\
\text { Unidades de Conservação da Natureza e dá outras } \\
\text { providências. }\end{array}$ \\
\hline $\begin{array}{l}\text { DECRETO FEDERAL } \mathrm{N}^{\circ} \\
1.922 / 1996\end{array}$ & $\begin{array}{l}\text { Dispõe sobre o reconhecimento das Reservas Particulares } \\
\text { do Patrimônio Natural e dá outras providências. }\end{array}$ \\
\hline $\begin{array}{l}\text { DECRETO FEDERAL } \mathrm{N}^{\circ} \\
99.274 / 1990\end{array}$ & $\begin{array}{l}\text { Regulamenta a Lei } \mathrm{n}^{\circ} 6.902 \text {, de } 27 \text { de abril de } 1981 \text {, e a } \\
\text { Lei } \mathrm{n}^{\circ} 6.938 \text {, de } 31 \text { de agosto de 1981, que dispõem, } \\
\text { respectivamente sobre a criação de Estações Ecológicas e } \\
\text { Áreas de Proteção Ambiental e sobre a Política Nacional } \\
\text { do Meio Ambiente, e dá outras providências. }\end{array}$ \\
\hline
\end{tabular}




\section{Sustentabilidade em Debate}

Tabela 2 - Características das unidades de conservação Estaduais de Santa Catarina (fonte: FATMA, 2004)

\begin{tabular}{|c|c|c|c|c|c|}
\hline $\begin{array}{c}\text { UC DE } \\
\text { PROTEÇÃO } \\
\text { INTEGRAL }\end{array}$ & $\begin{array}{c}\text { INSTRUMENTO } \\
\text { LEGAL DE } \\
\text { CRIAÇÃAO } \\
\end{array}$ & MUNICÍPIO & ÁREA (ha) & $\begin{array}{c}\text { TIPO DE } \\
\text { VEGETAÇÃO }\end{array}$ & $\begin{array}{c}\text { EX ISTËNCIA } \\
\text { DE PLANO } \\
\text { DE MANEJO }\end{array}$ \\
\hline
\end{tabular}

CATEGORIA: Parque Estadual (P.E.)

\begin{tabular}{|c|c|c|c|c|c|}
\hline $\begin{array}{l}\text { P.E. da Serra do } \\
\text { Tabuleiro }\end{array}$ & $\begin{array}{l}\text { Decreto } 1.260 \\
\text { de } 01.11 .75 \\
\end{array}$ & $\begin{array}{l}\text { Águas Mornas, } \\
\text { Florianópolis, } \\
\text { Garopaba, Imaruí, } \\
\text { Palhoça, Paulo } \\
\text { Lopes, Santo } \\
\text { Amaro da } \\
\text { Imperatriz, São } \\
\text { Bonifácio, São } \\
\text { Martinho } \\
\end{array}$ & 87405,00 & $\begin{array}{l}\text { Manguezal, } \\
\text { Restinga, } \\
\text { Floresta Ombrófila } \\
\text { Densa e Mista, } \\
\text { Floresta Nebular } \\
\text { e Campo } \\
\end{array}$ & $\begin{array}{l}\quad \text { Não } \\
\text { Possui } \\
\text { Zoneamento } \\
\end{array}$ \\
\hline $\begin{array}{l}\text { P.E. da Serra } \\
\text { Furada }\end{array}$ & $\begin{array}{l}\text { Decreto } 11.233 \mathrm{de} \\
20.06 .80\end{array}$ & $\begin{array}{l}\text { Grão Pará e } \\
\text { Orleans }\end{array}$ & $1.329,00$ & $\begin{array}{l}\text { Floresta } \\
\text { Ombrófila Densa }\end{array}$ & Não \\
\hline $\begin{array}{l}\text { P.E. das } \\
\text { Araucárias }\end{array}$ & $\begin{array}{l}\text { Decreto } 293 \\
\text { de } 30.05 .03\end{array}$ & $\begin{array}{l}\text { São Domingos e } \\
\text { Galvão }\end{array}$ & 625,11 & $\begin{array}{l}\text { Floresta } \\
\text { Ombrófila Mista }\end{array}$ & Sim \\
\hline $\begin{array}{l}\text { P.E. Fritz } \\
\text { Plaumann }\end{array}$ & $\begin{array}{l}\text { Decreto } 793 \\
\text { de } 24.09 .03\end{array}$ & Concórdia & 735,11 & $\begin{array}{l}\text { Floresta Estacional } \\
\text { Decidual }\end{array}$ & Sim \\
\hline $\begin{array}{l}\text { P.E. do Rio } \\
\text { Canoas }\end{array}$ & $\begin{array}{l}\text { Decreto } 1.871 \\
\text { de } 29.05 .04\end{array}$ & Campos Novos & $1.133,25$ & $\begin{array}{l}\text { Floresta } \\
\text { Ombrófila Mista }\end{array}$ & Não \\
\hline P.E. Acaraí & $\begin{array}{l}\text { Decreto } 3.517 \\
\text { de } 23.09 .05 \\
\end{array}$ & $\begin{array}{l}\text { São Francisco do } \\
\text { Sul }\end{array}$ & $6.667,00$ & $\begin{array}{l}\text { Restinga e Floresta } \\
\text { Ombrófila Densa }\end{array}$ & Não \\
\hline $\begin{array}{l}\text { P.E. do Rio } \\
\text { Vermelho }\end{array}$ & $\begin{array}{l}\text { Decreto } 308 \\
\text { de } 2007\end{array}$ & Florianópolis & $1.400,00$ & Restinga & Não \\
\hline \multicolumn{3}{|c|}{ Área total de Parques Estaduais } & $97.894,47$ & & \\
\hline
\end{tabular}

\section{CATEGORIA: Estação Ecológica - (ESEC)}

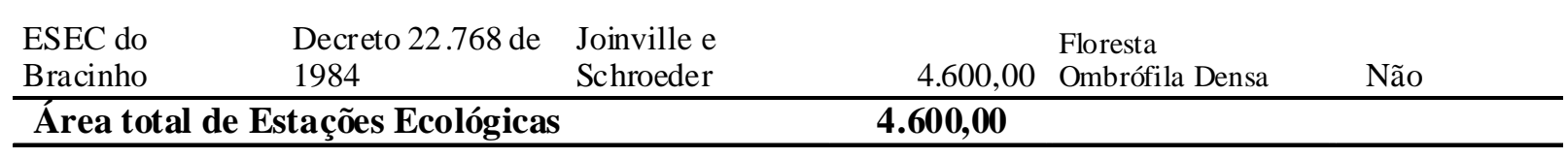

\section{CATE GORIA: Reserva Biológica - (REBIO)}

\begin{tabular}{|c|c|c|c|c|c|}
\hline $\begin{array}{l}\text { REBIO } \\
\text { do Aguaí }\end{array}$ & $\begin{array}{l}\text { Decreto } 19.635 \mathrm{de} \\
01.07 .83\end{array}$ & $\begin{array}{l}\text { Treviso, Nova } \\
\text { Veneza e } \\
\text { Siderópolis } \\
\end{array}$ & $7.672,00$ & $\begin{array}{l}\text { Floresta Ombrófila } \\
\text { Densa e Floresta } \\
\text { Nebular (crista da } \\
\text { serra Geral) } \\
\end{array}$ & Não \\
\hline $\begin{array}{l}\text { REBIO } \\
\text { da Canela Preta }\end{array}$ & $\begin{array}{l}\text { Decreto } 11.232 \text { de } \\
20.06 .80\end{array}$ & $\begin{array}{l}\text { Botuverá e Nova } \\
\text { Trento }\end{array}$ & $1.844,00$ & $\begin{array}{l}\text { Floresta } \\
\text { Ombrófila Densa }\end{array}$ & Não \\
\hline $\begin{array}{l}\text { REBIO } \\
\text { do Sassafrás }\end{array}$ & $\begin{array}{l}\text { Decreto } 2.221 \mathrm{de} \\
04.02 .77\end{array}$ & $\begin{array}{l}\text { Benedito Novo e } \\
\text { Doutor Pedrinho }\end{array}$ & $6.972,00$ & $\begin{array}{l}\text { Floresta } \\
\text { Ombrófila Densa }\end{array}$ & Não \\
\hline \multicolumn{3}{|c|}{ Área total de Reservas Biológicas } & $16.488,00$ & & \\
\hline \multicolumn{3}{|c|}{ Área total de UC Estaduais } & $118.982,47$ & & \\
\hline
\end{tabular}




\section{Unidades de Conservação de Santa Catarina}

\section{Parque Estadual das Araucárias}

Primeira unidade de conservação de araucárias sob a responsabilidade do Governo do Estado de Santa Catarina. O Parque Estadual das Araucárias (PEA) foi criado pelo Decreto $n^{\circ} .293$, de 30 de maio de 2003. Localizado no município de São Domingos, na Bacia do Rio Chapecó (figura 1), possui área de 612 hectares exclusivamente coberta por floresta ombrófila, comportando aproximadamente $10 \mathrm{mil}$ árvores remanescentes de reservas nativas.

Esse ecossistema encontra-se muito alterado, reduzido a manchas isoladas de vegetação, em função do desenvolvimento agropecuário e do extrativismo vegetal característicos da ocupação local (KLEIN, 1978). Nesse contexto, a criação de unidades de conservação no oeste do Estado de Santa Catarina, assume um importante papel para a perpetuação dos últimos remanescentes da floresta ombrófila mista, também conhecida como Mata de Araucárias (Figura 2).

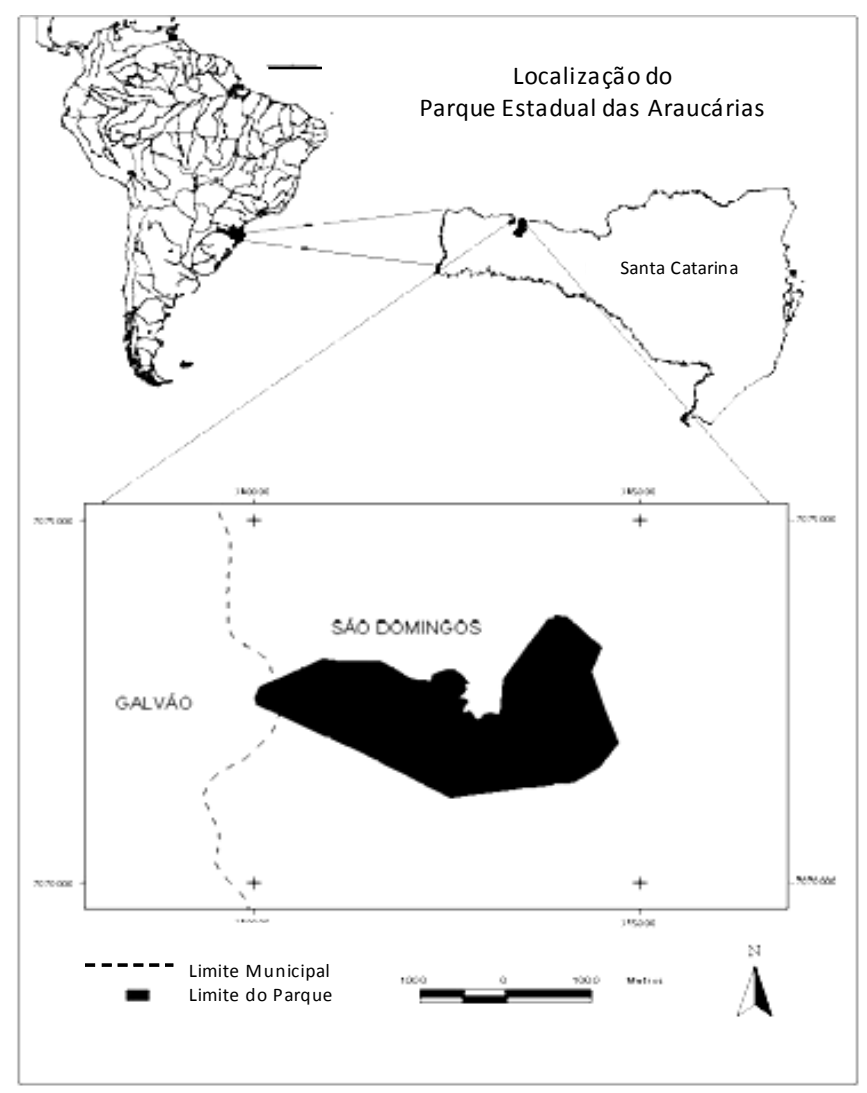

Figura 1 - Localização do Parque Estadual das Araucárias, nos municípios de Galvão e São Domingos, SC. (fonte: FATMA, 2004)

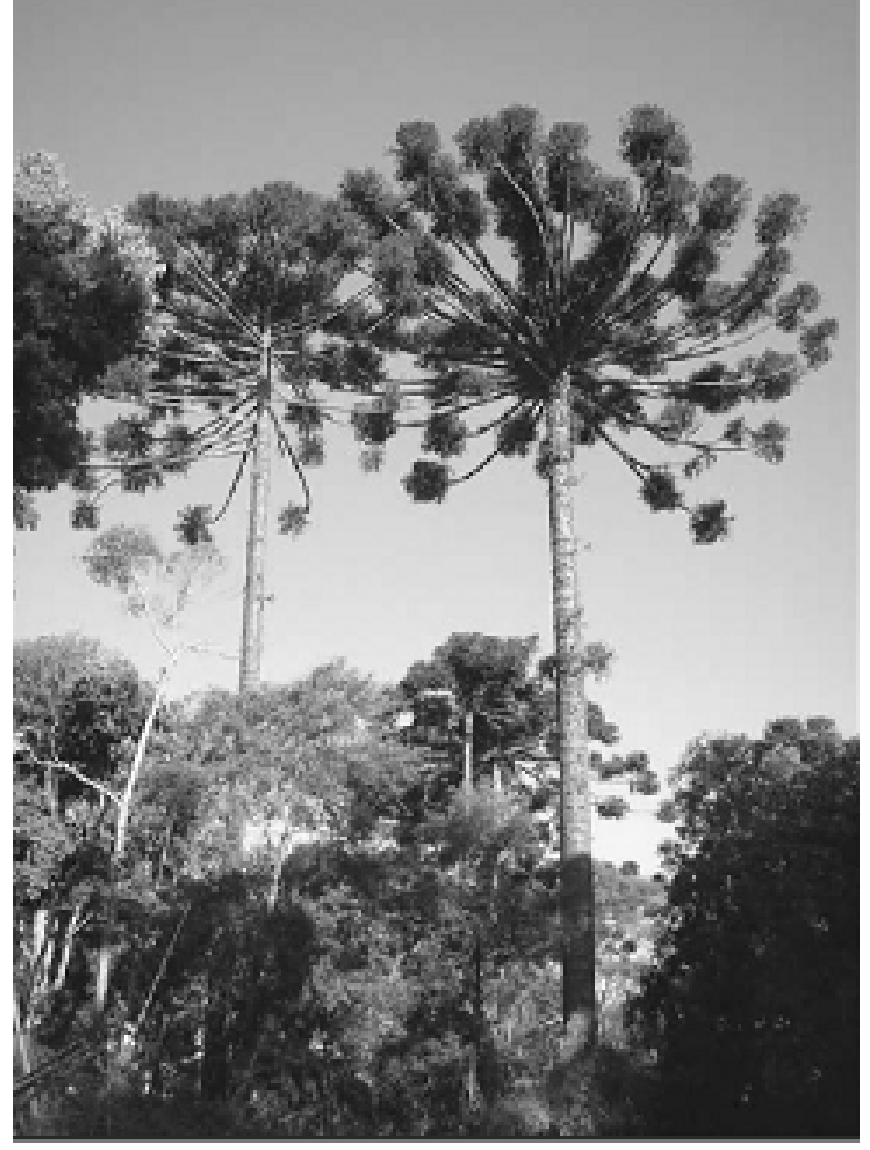

Figura 2 - Aspecto geral da vegetação de uma borda de Floresta com Araucárias, no Parque Estadual das Araucárias. (fonte: sítio FATMA)

Segundo o órgão gestor, durante a escolha da área destinada à criação da UC foi avaliado o estágio de conservação dos fragmentos florestais de relevante importância ecológica localizados nas áreas de influência da usina hidrelétrica de Quebra Queixo.

Conforme a FATMA (2004), dentre as principais motivações para criação dessa unidade de conservação está a busca por conter o desaparecimento das florestas de araucárias. Essas árvores já dominaram as terras da região, mas foram quase dizimadas, em pouco mais de 80 anos de extrativismo. Da cobertura original de araucárias existentes nos três Estados do Sul restam apenas 5\%, estando somente 0,22\% protegidas em parques. De acordo com KLEIN (1978) estima-se que sejam necessários mais de 100 anos para a constituição de florestas secundárias em estágio avançado de sucessão florestal.

Outra motivação relaciona-se ao abastecimento de água a municípios da região. Dentro do Parque encontra-se o rio Jacutinga, afluente do rio Bonito, 


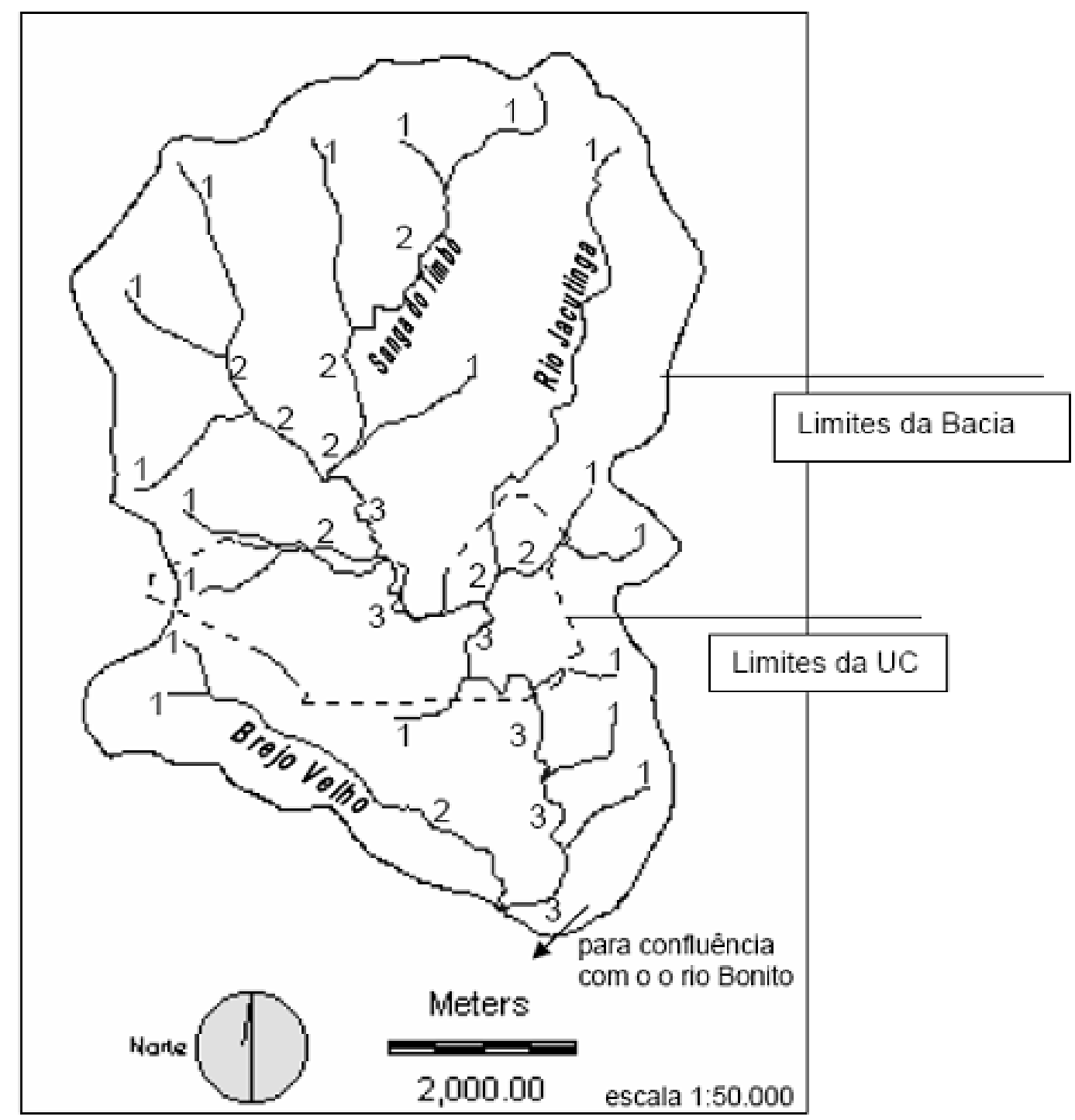

Figura 3 - Rede de drenagem da bacia do rio Jacutinga, município de São Domingos, SC. O número em cada afluente $(1,2,3)$ indica a ordem do curso. (fonte: FATMA, 2004)

importante afluente do rio Chapecó, e responsável pelo abastecimento de água do município de São Domingos (figura 3).

Dessa maneira, a indicação para criação do PEA se deu, principalmente, em virtude do a) alto grau de insularização da área; b) pela categoria de Parque admitir maior flexibilização quanto à definição de níveis de restrição; c) pela expectativa de usufruto da área pela população decorrente da implantação dos programas ambientais na área de influencia da UHE Quebra Queixo. Diante dessas questões a categoria Parque Estadual representou a escolha mais adequada, dentre as opções de Proteção Integral (Lei Fede- ral 9985/2000 - SNUC) visando aliar a conservação da biodiversidade regional com a educação ambiental ${ }^{1}$.

\section{Ameaças}

Originalmente, as imediações do PEA eram recobertas com vegetação característica do Bioma Mata Atlântica, possuindo altíssima riqueza e diversidade biológica e abrigando um grande número de espécies restritas a esse bioma. Acompanhando o cenário de degradação desse Bioma em outros locais, esta região teve sua vegetação original reduzida a fragmentos. 
Dada a intensa ocupação e exploração das florestas brasileiras, muitas das espécies florestais e representantes da fauna passaram a compor a lista de espécies consideradas raras ou ameaçadas de extinção, entre elas a Araucaria angustifolia (araucária).

Por se tratar de uma região com alta produtividade de grãos e criação de aves e suínos é observado o progressivo aumento da degradação ambiental local, provocado pelo uso excessivo e inadequado de agrotóxicos, usos e manejo impróprio do solo (influenciando seriamente a erosão) e pela concentração e manejo deficiente dos dejetos de suínos - séria problemática, já que os dejetos acabam por contaminar as fontes e pequenos mananciais próximos.

Outras atividades conflitantes são notadas dentro e fora da área protegida como: a pressão de caça e coleta de pinhão; áreas com lavouras; fluxo interno de veículos, além da presença de animais domésticos. Ao seu redor são encontradas extensas áreas de plantio de soja e milho, além de reflorestamento com Pinus. Conforme o cadastro de espécies exóticas in- vasoras do Instituto Horus, o PEA consta como local ameaçado pela presença de Hedychium coronarium espécie introduzida, com comportamento invasor (HORUS, 2007).

Diante desse cenário de uso e ocupação desordenado do espaço o que se observa, atualmente, é um estado avançado do processo de fragmentação do ecossistema florestal da região. O PEA, nessas condições, figura como um dos maiores remanescentes da Floresta Ombrófila Mista (FATMA, 2004).

\section{Parque Estadual Fritz Plaumann}

O Parque Estadual Fritz Plaumann está localizado no município de Concórdia, no Estado de Santa Catarina, às margens do Rio Uruguai (figura 4).

Instituído pelo decreto $\mathrm{n}^{\circ} 797$, de 24 de setembro de 2003, o Parque Estadual Fritz Plaumann foi criado como medida de compensação ambiental pelo aproveitamento hidrelétrico da usina de Itá, na bacia hidrográfica do rio Uruguai (FATMA, 2005).
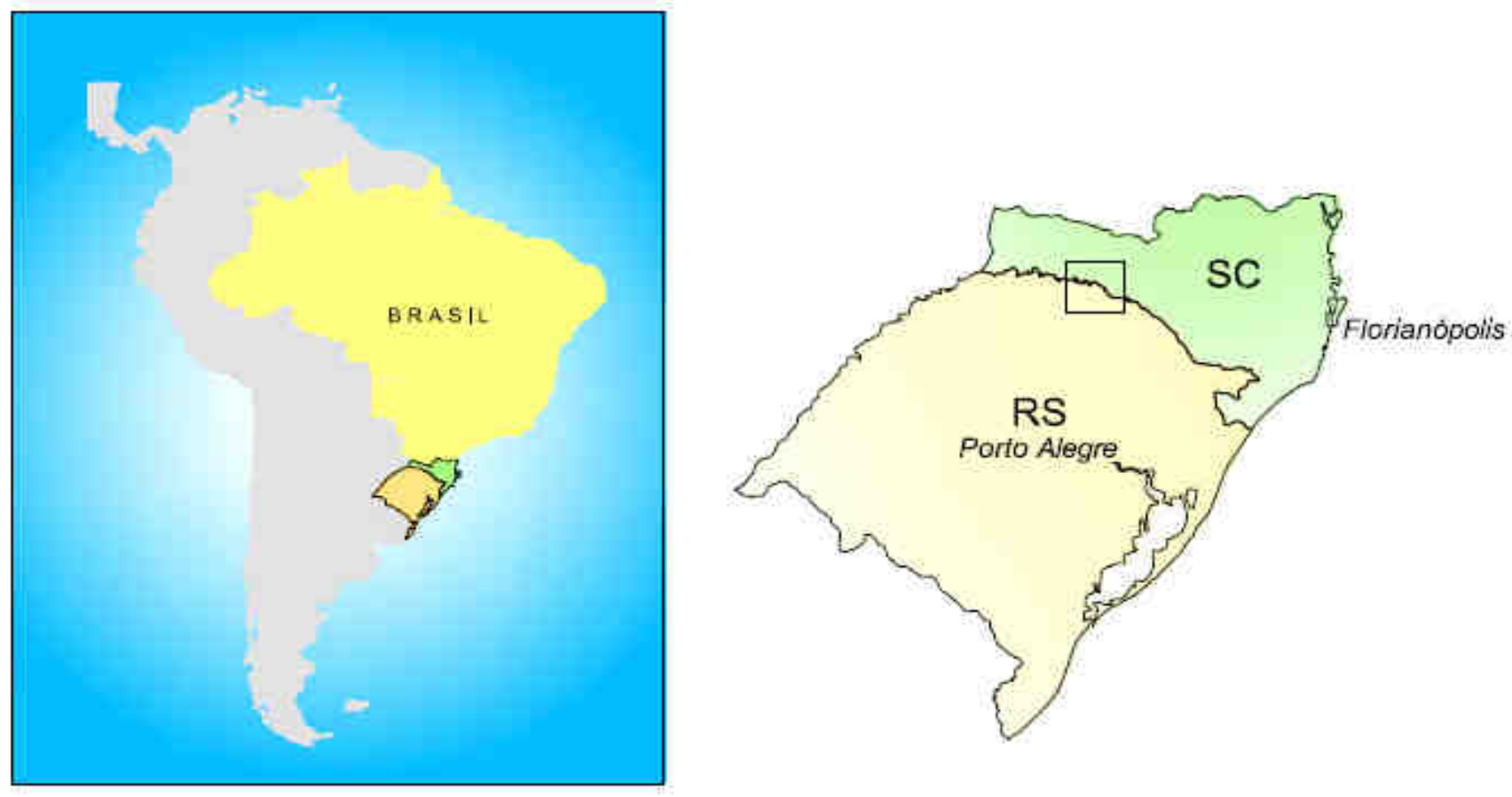

Figura 4 - Localização do Parque Estadual Fritz Plaumann. (fonte: FATMA, 2005) 


\section{Sustentabilidade em Debate}

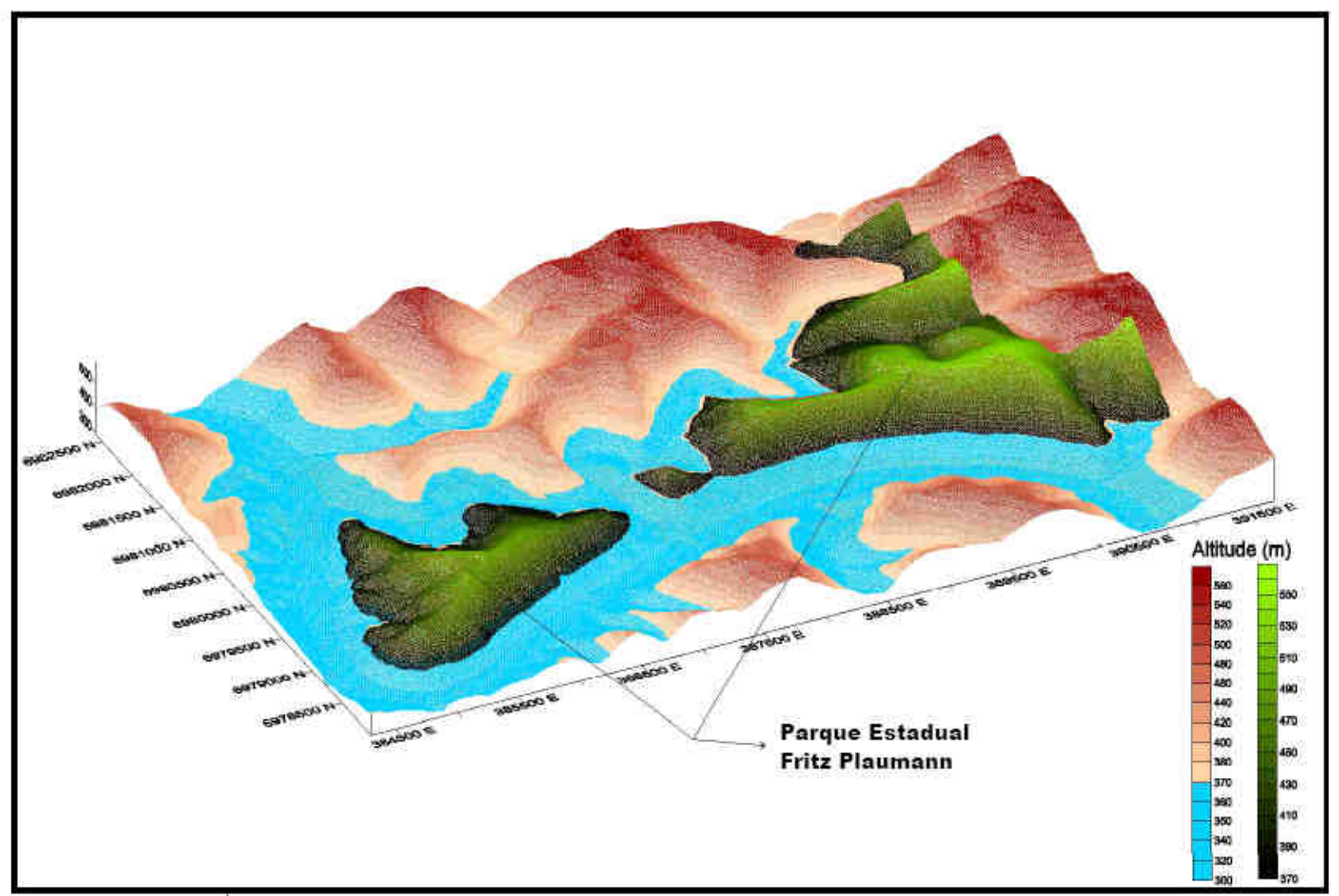

Figura 5 - Modelo do terreno e drenagem que necessita de ações especiais de planejamento e conservação. (fonte: FATMA, 2005)

Inserido na região do Alto Rio Uruguai, o Parque é a primeira e única unidade de conservação da Floresta Estacional Decidual no Estado de Santa Catarina, abrangendo uma área de 741 hectares. O Plano de Manejo da Unidade já foi elaborado e teve sua versão eletrônica disponível em 2007 no website da FATMA.

O nome dado ao Parque é uma homenagem ao alemão Fritz Plaumann, naturalista e entomologista, que se dedicou à pesquisa de invertebrados da fauna brasileira por 60 anos, alertando em suas análises para as alterações ambientais ocorridas na região oeste do planalto catarinense.

A vegetação original da Floresta Estacional Decidual era representada por espécies arbóreas de grande porte, atingindo de 30 a 40 metros de altura sem, contudo, formarem uma cobertura superior contínua. O clima com duas estações marcantes, uma chuvosa e outra seca, favorece a ocorrência desse tipo de vegetação (FATMA, 2005).

Atualmente esse ecossistema encontra-se extremamente fragmentado, sendo considerado uma das formações vegetais mais ameaçadas dos domínios da Mata Atlântica. Em razão disso, o Parque Estadual Fritz Plaumann, apesar de relativamente pequeno, representa uma área de significativa importância num esforço de conservação desse ecossistema.

Em função da exploração predatória devido às atividades agrícola, pecuária e exploração madeireira, a região apresenta pequenos remanescentes da Floresta Estacional Decidual (Floresta do rio Uruguai), cobertura vegetal que prevalecia na maior parte do Vale do rio Uruguai (FATMA, 2005).

Outra preocupação diz respeito às atividades e consequiências das ações antrópicas desenvolvidas nesta região, na bacia hidrográfica vale do rio do Peixe. Essa área é de significativa importância, geográfica e ambiental, pois, alterações do meio interferem na unidade de conservação.

A drenagem das águas (figura 5) de toda a bacia do rio dos Queimados, considerado "intensamente poluído", se dirige para a área da UC, comprometendo a qualidade dos atributos ambientais e físicoquímicos locais. De acordo com o cadastro de fon- 


\section{Unidades de Conservação de Santa Catarina}

tes poluidoras do rio dos Queimados, realizado pela FATMA, estão relacionadas diversas atividades que geram resíduos cujo corpo receptor é o sistema de drenagem. Dentre elas pode-se citar os curtumes, abastecimento de combustíveis (lavagem e lubrificação), suinocultura, abatedouros de bovinos e suínos.

O impacto negativo e a destruição dos ambientes naturais da região onde está inserida a UC revelase como um dos principais fatores que influenciam negativamente a fauna e flora local. Tais alterações ambientais contribuem para o empobrecimento gradativo da diversidade biológica ali presente. Fato este evidenciado pela constante inclusão de espécies em listas de fauna ameaçada de extinção, dentre elas, as raras e as endêmicas - consideradas vulneráveis ao completo desaparecimento (FATMA, 2007; RYLANDS \& BRANDON, 2005).

Assim, com o propósito de preservar os últimos remanescentes da Florestal Estacional Decidual na re- gião de Concórdia e a biodiversidade ali compreendida foi instituída a unidade de conservação Fritz Plaumann.

Na medida em que as ações de manejo previstas para a área condicionem mudanças na realidade, o contexto atual pode ser melhorado, uma vez que a diversidade biológica está intrinsecamente relacionada com a complexidade da vegetação e o equilíbrio das funções ecológicas do sistema (RYLANDS \& BRANDON, 2005).

\section{Parque Estadual Rio Canoas}

Criado pelo decreto $\mathrm{n}^{\mathrm{o}} 1.871$, de 27 de maio de 2004, a área do Parque Estadual Rio Canoas foi doada pela Enercan, empresa privada, ao Governo de Santa Catarina como medida de compensação ambiental pelo aproveitamento hidrelétrico de Campos Novos, na bacia hidrográfica do rio Canoas (FATMA, 2007).

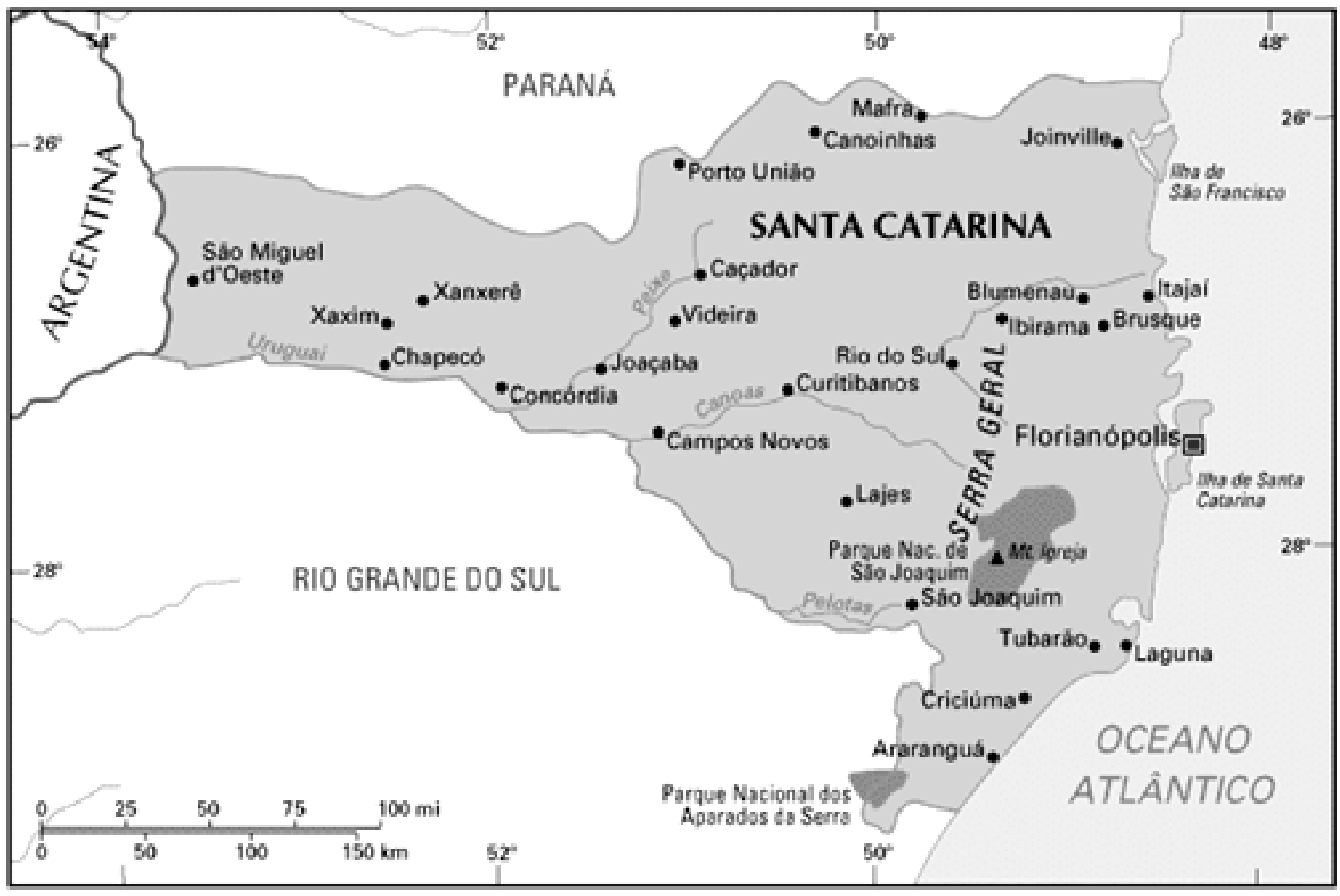

Figura 6 - Mapa de Santa Catarina: localização de Campos Novos. (fonte: sítio FATMA) 


\section{Sustentabilidade em Debate}

Localizado próximo à Barra do rio Ibicuí, no município de Campos Novos (figura 6), o Parque abrange a vegetação da Floresta Ombrófila Mista ou Floresta de Araucária e sua área conta com aproximadamente 1.200 hectares.

Dentre os elementos motivadores para a implementação do Parque Estadual Rio Canoas estão a) a presença de espécies da fauna e flora em extinção, como a araucária, a imbuia e o xaxim; b) a possibilidade de conservação, manejo e aproveitamento científico da fauna e flora; c) e o desempenho de atividades de educação ambiental e àquelas que envolvam o turismo ecológico.

Dentre as ações desenvolvidas pela Enercan (Campos Novos Energia S.A) no âmbito dos programas ambientais colocados em prática como medida de compensação ambiental pela construção da Usina Hidrelétrica Campos Novos estão: o plantio de 240 mil mudas de árvores nativas na Área de Preservação Permanente (APP); a construção de um viveiro florestal e um espaço de visitação pública, aonde foi desenvolvido um trabalho de educação ambiental com as crianças e escolas da região; a recuperação de áreas degradadas e, o monitoramento e conservação da flora e fauna local. Não foram encontrados dados sobre os resultados do trabalho com educação ambiental, recuperação, monitoramento ou conservação.

A falta de dados e informações adicionais sobre o atual estado e condições de gestão do Parque Estadual Rio Canoas comprometeu uma análise mais detalhada desta UC.

\section{Parque Estadual de Acarai}

O Parque Estadual de Acaraí foi instituído pelo Decreto $n^{\circ} 3.517$, em 23 de setembro de 2005. Situado no litoral norte do Estado de Santa Catarina, no município de São Francisco do Sul, possui uma área de aproximadamente 6.667 ha, abrangendo a restinga da Praia Grande e todo o complexo hidrológico do rio Acaraí, nascentes do rio Perequê e lagoa do Capivaru (FATMA, 2007).

O Parque foi definido buscando um arranjo espacial que visa manter as funções ambientais desempenhadas pela restinga da Praia Grande e de parte do

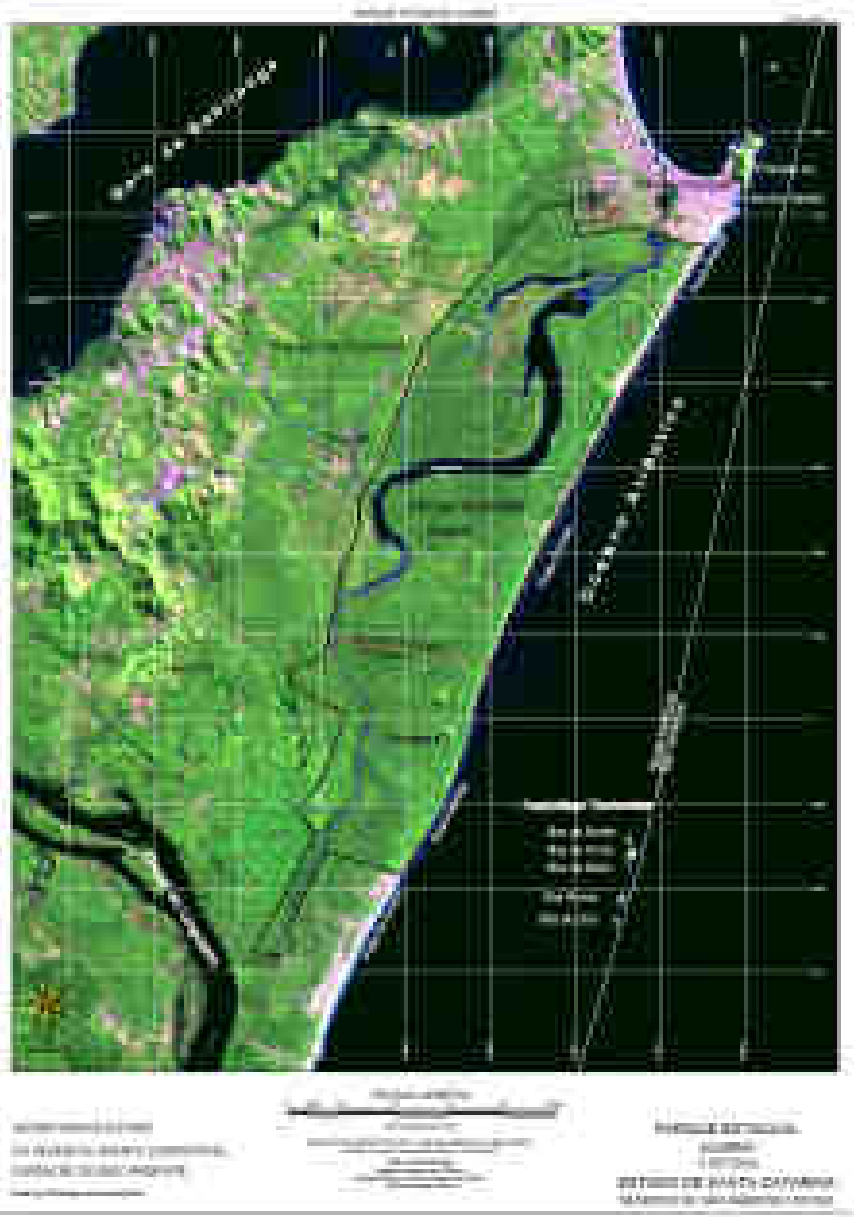

Figura 7 - Mapa do Parque Estadual de Acarai. (fonte: sítio FATMA)

complexo hidrológico contido neste. As ilhas do arquipélago de Tamboretes também compõem a UC, garantindo a proteção das espécies de aves marinhas que as utilizam para reprodução, nidação e descanso durante as rotas de migração (figura 7).

O complexo hídrico existente nesta área é, ainda, responsável pelo abrigo, reprodução e alimentação de várias espécies aquáticas, que somado à vegetação de restinga e de Floresta das Terras Baixas do Domínio da Mata Atlântica constituem local para proteção da flora e fauna, endêmicas e ameaçadas de extinção.

Por ser uma região que detém relevantes características naturais, alta diversidade biológica e significativa importância para o conhecimento de nossa história pré-colonial e colonial, recebeu inúmeras manifestações por parte da comunidade cientifica e sociedade civil em prol da criação desse Parque Estadual. 


\section{Unidades de Conservação de Santa Catarina}

A oportunidade para instituição da UC ocorreu por meio do pagamento de compensação ambiental pela instalação de empreendimento da Vega do Sul (unidade industrial de galvanização de aço).

Segundo a FATMA, a criação do Parque Estadual de Acaraí é uma oportunidade para o estabelecimento de uma política territorial direcionada a estabelecer a diferenciação e intensidade de uso, priorizando a proteção de seus recursos naturais e culturais. Assim sendo, buscou-se ordenar as atividades de uso atuais e potenciais, de forma a contribuir para a conservação dos recursos naturais, sensibilização dos visitantes para a conservação da natureza, bem como retorno de benefícios às populações do entorno.

Entretanto, pressões de cunho público passaram a incorrer para que o Parque Estadual de Acaraí se tornasse uma unidade de uso sustentável. O Ministério Público Federal e o Ministério Público de Santa Catarina ajuízam uma ação civil pública, alegando que apesar de terem sido elaborados os estudos técnicos sobre os ecossistemas presentes na região, a FATMA não realizou os estudos sócioambientais e sócio-econômicos, que tratam do modo de vida dos moradores tradicionais daquelas áreas.
Esses estudos também são necessários à definição da categoria de unidade de conservação a ser adotada.

As unidades de proteção integral, classificação atual do Parque Estadual do Acaraí, têm como objetivo básico preservar a natureza, sendo admitido apenas o uso indireto dos seus recursos naturais. Já as unidades de uso sustentável permitem a compatibilização entre a conservação da natureza e o uso sustentável de parte dos seus recursos. Como a região do parque é ocupada há mais de um século, por comunidades que se utilizam dos seus recursos naturais para consumo direto ou para a confecção de artesanato, assim como estabeleceram portos ao longo do rio Acaraí para a pesca e detém grande conhecimento sobre gerenciamento e conservação da área, entende-se que a unidade de uso sustentável seria o modelo mais adequado para a criação de uma unidade de conservação naquele local (MP SC, 2007)

\section{Parque Estadual da Serra do Tabuleiro}

É a maior e mais antiga unidade de conservação de Santa Catarina. Ocupa aproximadamente 1\% do território do Estado, com uma extensão de 87.405 hectares. Foi criado por meio do Decreto $n^{\circ} 1.260 /$

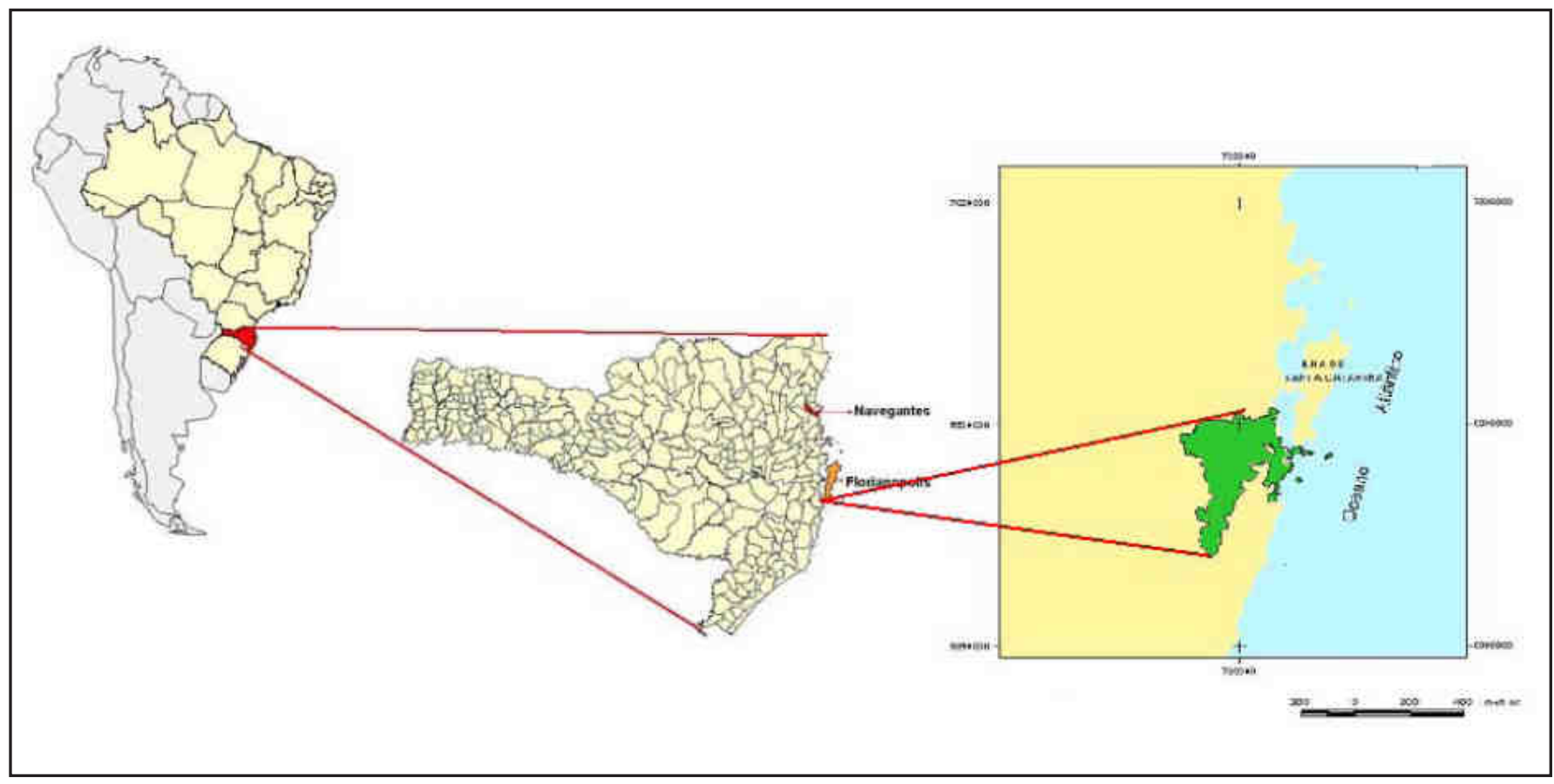

Figura 8 - Mapa de localização do Parque Estadual Serra do Tabuleiro.

(fonte: sítio FATMA) 


\section{Sustentabilidade em Debate}

75 e abrange áreas de nove municípios: Florianópolis, Palhoça, Santo Amaro da Imperatriz, Águas Mornas, São Bonifácio, São Martinho, Imaruí, Garopaba e Paulo Lopes. Engloba, também, as ilhas de Fortaleza/Araçatuba, Ilha do Andrade, Papagaio Pequeno, Três Irmãs, Moleques do Sul, Siriú, Coral, dos Cardos e a ponta sul da ilha de Santa Catarina (figura 8) (IBAMA, 2007).

$\mathrm{O}$ parque tem uma composição vegetal rica e mista, reunindo cinco das seis formações botânicas do Estado. Começa no litoral, com a paisagem da restinga, sobe a serra, alcançando o planalto em meio à vegetação dos pinhais, perpassando pela floresta pluvial da encosta atlântica, vegetação da matinha nebular e os campos de altitude da chapada da Serra. Entre a vegetação formam-se rios e córregos que serão responsáveis pelo fornecimento da água potável utilizada pelos moradores de toda Grande Florianópolis (FATMA, 2007).

A maior parte do parque está coberta por mata atlântica, ecorregião terrestre considerada por estudo do Banco Mundial, área de máxima prioridade regional para a conservação da biodiversidade. Outro estudo recente, também do Banco Mundial, inclui o Parque Estadual da Serra do Tabuleiro na lista dos habitats naturais críticos, localizados na região da América Latina e do Caribe.

A sede do parque fica às margens da BR-101, no município de Palhoça, a 40 km de Florianópolis, em direção ao Sul do Estado. O centro de visitantes é a maior edificação, com $270 \mathrm{~m}^{2}$ de área construída e auditório para 80 pessoas, área para administração, oficinas de educação ambiental, recepção e banheiros, inclusive para deficientes. A trilha de $1.000 \mathrm{~m}$ permite caminhar por partes da sede do Parque antes inacessíveis, localizada na Baixada do Maciambu, pode ser feita com o auxilio de guias-monitores e permite aos visitantes conhecerem uma área de restinga, observando a fauna e a vegetação local (FATMA, 2007).

As obras foram realizadas com recursos da Transportadora Brasileira Gasoduto Brasil-Bolívia S/A TBG, em convênio com o Governo do Estado como parte do Plano de Compensação Ecológica referente à construção do Gasoduto Bolívia-Brasil e da Empresa Catarinense de transmissão de Energia - ECTE, como parte do Plano de Compensação Ecológica referente à Linha de transmissão Campos Novos/Blumenau.

$\mathrm{O}$ parque ainda não possui plano de manejo, porém, como instrumento de gestão se utiliza do Zoneamento do Parque Estadual da Serra do Tabuleiro (PEST), produto do Mapeamento Sócio-Econômico do PEST (FATMA, 2007). Esse produto foi realizado por meio da compilação de dados secundários disponíveis e do levantamento de dados primários obtidos em campo, dispondo de informações sócio-econômicas fundamentais para a posterior elaboração do Plano de Manejo do parque.

O referido estudo parte de uma caracterização sócio-econômica regional da área onde está inserida o Parque Estadual da Serra do Tabuleiro. Em seguida, faz um diagnóstico de cada um dos municípios cujas terras compõem a unidade de conservação, detalha as características da região de entorno e área de influência direta, abordando as 57 localidades envolvidas; seguinte a estas caracterizações sócio-econômicas são descritos e analisados os aspectos fundiários internos ao parque. Por fim, aborda detalhadamente o patrimônio histórico-cultural e os atrativos naturais presentes nesta importante área correspondente à UC.

Dentro de um projeto financiado pelo banco alemão KFW, realizado entre 2002 e 2006, recursos foram investidos em diversos setores da gestão das UCs, inclusive na criação de novas logomarcas das unidades. A antiga logomarca do Parque do Tabuleiro foi recriada, tendo sido a primeira providência substituir o cisne, espécie que já não ocorre mais na região, pelo jacaré-do-papo-amarelo, espécie nativa (FATMA, 2007).

Detalhes como esses reforçam a necessidade em direcionar recursos e definir ações prioritárias a fim de obter uma gestão efetiva das unidades de conservação Estaduais.

\section{Parque Estadual da Serra Furada}

Criado em 20 de junho de 1980, pelo decreto estadual $n^{\circ} 11.233$, o Parque Estadual da Serra Furada (PESF) abrange os municípios de Orleans e GrãoPará e tem uma área de 1.329 hectares. A vegetação é composta, predominantemente, por Floresta Atlân- 
tica, recortada por diversos córregos e seu relevo é extremamente acidentado e de grande beleza o que confere ao Parque um grande potencial turístico (FATMA, 2007). O PESF tem esse nome devido a um furo existente em uma grande rocha, que pode ser avistado de longe (figura 10).

No cadastro de espécies exóticas invasoras do Instituto Horus, o PESF consta como local ameaçado pela presença do Pinus, espécie introduzida, com comportamento altamente invasor (HORUS, 2007).

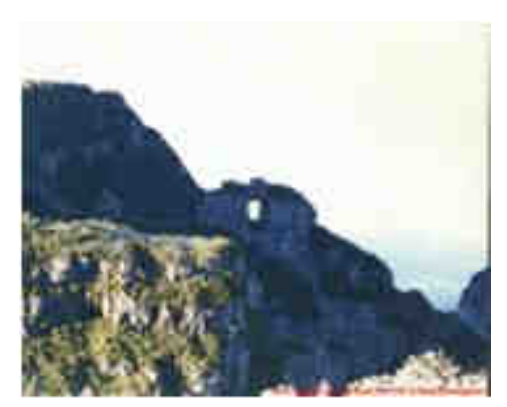

Figura 9 - Detalhe da formação rochosa que dá nome ao Parque. (fonte: sítio FATMA)

\section{Reserva Biológica Estadual do Sassafrás}

As reservas biológicas são locais de proteção integral destinadas, exclusivamente, para pesquisa e educação. A REBIO do Sassafrás, criada em 4 de fevereiro de 1977 , por meio do decreto $\mathrm{n}^{\circ} 2.221$, é dividida em duas áreas: uma com 3.862 hectares no município de Doutor Pedrinho, outra com 1.361 hectares no município de Benedito Novo (IBAMA, 2007).

Abrigando uma área remanescente da Floresta Atlântica, a reserva ganhou esse nome por ser o habitat da canela sassafrás (Ocotea pretiosa), uma espécie de árvore que se encontra ameaçada de extinção e que ocorre no local.

A porção que corresponde a maior área da REBIO é a que permanece mais bem preservada. Coberta por uma densa vegetação, apresenta relevo bastante acentuado, com inúmeros vales cortados por córregos e cachoeiras (FATMA, 2007).

$$
* * *
$$

\section{Reserva Biológica Estadual da Canela Preta}

Estendendo-se pelos municípios de Botuverá e Nova Trento, esta reserva foi fundada em 20 de junho de 1980, pelo decreto 11.232, com área de 1.844 hectares. Posteriormente, foram anexados 55 hectares por meio do Decreto 4.840, de 23 de setembro de 1994, totalizando 1.899 hectares (FATMA, 2007).

Segunda o IBAMA (2007), a canela preta (Ocotea catharinensis) é uma espécie da flora brasileira característica do bioma Mata Atlântica e está ameaçada de extinção. De acordo com REITZ et al (1978) a canela preta chega a representar até um terço do volume em madeira em matas primárias na floresta Ombrófila Densa de Santa Catarina. Devido a qualidade de sua madeira e o amplo uso para que se presta, essa espécie foi severamente explorada no Estado.

Na REBIO Estadual da Canela Preta ainda é predominante a ocorrência dessa espécie, assim como, grande quantidade de palmiteiros. A região tem diversos morros, formando vales, aonde correm rios que formarão a bacia do rio Itajaí-Açú e a do rio Tijucas (FATMA, 2007).

\section{Reserva Biológica Estadual do Aguaí}

"Aguaí" é o nome popular de uma árvore, conhecida como Chrysophyllum viride. Esta espécie, característica da Mata Atlântica, ocorre nos Estados de São Paulo, Paraná e Santa Catarina, recebendo nomes diferentes de acordo com a região, como caxeta, aguaizeiro, caxeta-amarela, coerana. Os seus frutos fornecem alimentação para animais silvestres.

Considerada a segunda maior unidade de conservação no Estado e a maior em sua categoria, a Reserva Biológica Estadual do Aguaí abrange os municípios de Meleiro, Siderópolis e Nova Veneza. Esta reserva foi criada em $1^{\circ}$ de junho de 1983 , por meio do decreto $\mathrm{n}^{\circ}$. 19.635, com área de 7.672 hectares. O principal motivo de sua criação foi o relevo acidentado com altitudes que variam dos 200 aos 1.200 metros e a presença de diversos canyons (FATMA, 2007).

Nesses locais nasce uma grande quantidade dos rios que formarão a bacia carbonífera. As nascentes 


\section{Sustentabilidade em Debate}

são protegidas por uma vegetação densa formada pela Floresta Atlântica e Floresta Nebular, no alto da serra. Sua importância é ainda maior por constituir, juntamente com o Parque Estadual da Serra do Tabuleiro, o Parque Estadual da Serra Furada, o Parque Nacional de São Joaquim, o Parque Nacional da Serra Geral e o Parque Nacional dos Aparados da Serra um corredor ecológico (IBAMA, 2007; FATMA, 2007).

Atualmente, a Reserva Biológica do Aguaí ainda não é demarcada e não tem marcos implantados. Seus limites foram lançados sobre folhas topográficas do IBGE na Escala 1: 50.000 (FATMA, 2007). O acesso a um dos limites da UC, na localidade de Rio da Serra, pode ser feito pelo Município de Nova Veneza, passando pela Barragem e Adutora do Rio São Bento.

Embora a reserva biológica não possua um plano de manejo consolidado, um projeto de pesquisa sobre felinos vem sendo realizado, com recursos de uma empresa privada (MDS, do ramo de peças automotivas).

\section{Parque Estadual do Rio Vermelho}

Criado na década de 1960, como área experimental para plantação de pinus e eucalipto, o local deixou de ser uma estação experimental para ser enquadrado na categoria de Parque Florestal.

Em maio de 2007, o antigo Parque Florestal do Rio Vermelho passou a compor a categoria de Parque Estadual do Rio Vermelho (Decreto Estadual $N^{\circ} 308 / 2007$ ). Entre as razões para a troca de nomenclatura está no fato do Sistema Nacional de Unidades de Conservação (SNUC) não prever a categoria "parque florestal" em suas diretrizes. Assim, depois de um levantamento realizado por equipe técnica, nomeada pelo governo do Estado, a melhor categoria ponderada para a unidade foi a de Parque Estadual. Estudos foram realizados considerando os aspectos topográficos e os limites da área, além do mapeamento da fauna e flora (FATMA, 2007).

O Parque Estadual do Rio Vermelho está localizado na ilha de Santa Catarina, em Florianópolis, compreende 1.400 hectares ao norte da ilha, desses
500 ha correspondem a áreas de plantio de Pinus. Em 40 anos, aproximadamente, 250 ha de dunas fixas e semi-fixas foram comprometidas devido à interferência do Pinus (espécie invasora), provocando uma expressiva mudança na paisagem litorânea. As plantas de restinga que crescem sob os talhões de Pinus têm seu processo reprodutivo inibido, não apresentando frutificação. Este fato figura como uma das principais causas que dificultam a sobrevivência da fauna do Parque Estadual do Rio Vermelho (AC UFSC, 2007).

O Parque é delimitado a leste pela praia do Moçambique e a oeste pela Lagoa da Conceição. Até a presente data, a UC é administrada pela Companhia Integrada de Desenvolvimento Agrícola de Santa Catarina (CIDASC) e não possui plano de manejo estruturado.

\section{Estação Ecológica do Bracinho}

Localizada na região oeste do município de Joinville a Estação Ecológica do Bracinho (ESEC Bracinho) possui aproximadamente 4600 ha e abrange parte do município de Schroeder. Em sua área de abrangência apresenta relevo acidentado e abriga as nascentes dos rios Bracinho e Piraí.

A área da ESEC, antes pertencente à companhia de água e saneamento local, foi criada em 1984, pelo Decreto 22.768 , com a finalidade de realizar pesquisa básica e aplicada, assim como o desenvolvimento de ações no âmbito da educação ambiental. Sua importância também está atrelada à manutenção do regime hidrológico com vistas ao abastecimento regular das represas, que acumulam a água utilizada nas usinas hidrelétricas da região. A ESEC até o fechamento deste estudo não possuía plano de manejo como instrumento norteador da gestão da UC.

\section{Outras Unidades de Conservação no Estado de Santa Catarina}

A tabela 3 apresenta de maneira sistematizada, as informações contidas no cartograma anexado (FATMA-DEAM, 2004) sobre as demais unidades de conservação presentes em Santa Catarina e correspondentes enquadramentos de categoria. 


\section{Unidades de Conservação de Santa Catarina}

Tabela 3 - Demais unidades de conservação de Santa Catarina

\begin{tabular}{|c|c|l|}
\hline Categoria & Quantidade & \multicolumn{1}{c|}{ Observações } \\
\hline UCs Federais & 14 & $\begin{array}{l}\text { Seis delas correspondem a UCs de } \\
\text { "proteção integral" e as demais de } \\
\text { "uso sustentável"2 }\end{array}$ \\
\hline UCs Municipais & aproximadamente 43 & $\begin{array}{l}\text { Esse número é inexato pois algumas } \\
\text { áreas não possuem confirmação } \\
\text { sobre a categoria pertencente; }\end{array}$ \\
\hline Reservas Particulares & 35 & $\begin{array}{l}\text { Esse quantitativo corresponde à } \\
\text { reservas particulares já criadas ou } \\
\text { em processo de criação, conforme } \\
\text { detalha a legenda do cartograma; }\end{array}$ \\
\hline $\begin{array}{c}\text { Áreas Protegidas não enquadradas } \\
\text { no SNUC ou no Sistema Estadual de }\end{array}$ & \multirow{2}{*}{$\begin{array}{l}\text { Após a elaboração do cartograma, } \\
\text { uma delas tornou-se Parque Estadual } \\
\text { (PE do Rio Vermelho) e as demais } \\
\text { são áreas não regulamentadas como } \\
\text { UCs, embora sejam consideradas } \\
\text { protegidas, conforme lista } \\
\text { áreas do } \\
\text { apresentada na legenda } \\
\text { cartograma anexo. }\end{array}$} \\
\hline
\end{tabular}

\section{Considerações Finais}

As alterações ambientais levam invariavelmente ao empobrecimento gradativo da diversidade biológica local e sistêmica. Fato este evidenciado pela constante inclusão de espécies da flora e fauna brasileira em listas de espécies ameaçadas de extinção e pelo acelerado processo de fragmentação e redução dos ecossistemas naturais observado nas últimas décadas (LEWINSOHN \& PRADO, 2005; CHAPIN, 2000).

A falta de uma política agrícola e o uso de métodos de manejo do solo inadequados, bem como a especulação imobiliária e a crescente ocupação desordenada dos espaços territoriais catarinenses têm colocado em risco o patrimônio natural do Estado. Tal processo de ocupação do espaço geográfico de Santa Catarina condicionou, ao longo dos anos, intensa pressão e impacto negativo sobre os seus recursos naturais, entre eles a redução, fragmentação e isolamento do Bioma Mata Atlântica e dos ecossistemas a ele associados.

O que se observa, atualmente, são ações dirigidas à preservação da água, do solo, do ar, da fauna e da flora, ainda, muito tímidas e insuficientes frente à intensidade e velocidade da degradação. Neste contex- to, a priorização de ações de conservação nos reduzidos espaços que, ainda abrigam significativos remanescentes dos ecossistemas marinhos, costeiros e florestais torna-se de suma importância.

Diante desse cenário a instituição de unidades de conservação figura-se como uma estratégia efetiva para a conservação do patrimônio natural e para a manutenção das funções ecológicas desempenhadas nos ecossistemas (FERREIRA et al., 2005).

É importante ressaltar que nem todas as unidades de conservação criadas possuem suporte e condições adequadas no sentido de atender os objetivos que justificaram a sua criação. Assim como, nem sempre o conjunto dessas unidades forma um sistema eficiente que contemple significativas parcelas de representatividade dos ecossistemas e espécies relevantes para a conservação.

Corroborando RYLANDS \& BRANDON (2005), o fortalecimento da gestão das áreas protegidas já existentes é importante ser considerado quando se objetiva a efetividade de uma UC instituída. Ações como a própria elaboração de planos de gestão, também conhecidos como planos de manejo são pilares centrais para a estruturação das UCs.

O Estado de Santa Catarina instituiu, até o momento, onze unidades estaduais de conservação den- 


\section{Sustentabilidade em Debate}

tro das categorias conhecidas como: Parque Estadual, Reserva Biológica e Estação Ecológica. O número de Reservas Particulares do Patrimônio Natural (RPPN) levantadas no Estado revela um potencial ainda a ser explorado. No entanto, por não possuir legislação sobre ICMS Ecológico, Santa Catarina acaba por não oferecer este importante incentivo à criação de RPPNs. Entendemos ser este um aspecto que mereça ser repensado como estratégia, já que as RPPNs figuram como interessante instrumento complementar de conservação, principalmente se fomentado no entorno ou próximo de unidades de conservação de uso sustentável.

Nos levantamentos para obtenção de informações que para esse estudo foi possível notar que o processo de criação de parte das UCs Estaduais em SC esteve atrelado às empresas privadas, sob a forma de compensação ambiental - recurso também destinado para a estruturação de diversas UCs e para o apoio à programas e projetos relacionados à conservação do patrimônio natural.

Ainda, por meio de uma consulta comparativa no Cadastro Nacional de Unidades de Conservação (CNUC), notou-se que Santa Catarina perde em quantidade de unidades de conservação estaduais para os Estados do Paraná e Rio Grande do Sul. Outro aspecto observado foi que o Órgão Estadual de Meio Ambiente de Santa Catarina não cadastrou no CNUC as UCs estaduais catarinenses, apesar de estar cadastrada como gestora das mesmas. Um dos benefícios do cadastramento das UCs no CNUC é a possibilidade de acesso aos recursos advindos da Compensação Ambiental.

Assim, a análise conduzida sobre o estado da arte relacionado às unidades de conservação de Santa Catarina assinala a importância em implementar políticas públicas efetivas, direcionadas a atender os objetivos das diferentes categorias de UCs, possibilitando que estas cumpram suas finalidades de criação contribuindo, assim, para a conservação e manutenção do patrimônio natural do Estado e, em perspectiva mais ampla, do Brasil.

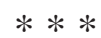

\section{Referências Bibliográficas}

AC UFSC - Assessoria de Comunicação da Universidade Federal de Santa Catarina. Disponível em: http://www.ambientebrasil.com.br/noticias/index.php 3 ?action=ler\&id=9889. Consultado em 08/12/2007. BRASIL. Lei n. ${ }^{\circ}$ 9.985, de 18 de julho de 2000. Regulamenta o art. 225, § 1o, incisos I, II, III e VII da Constituição Federal, institui o Sistema Nacional de Unidades de Conservação da Natureza.

CHAPIN, F. S. et al. Consequences of changing biodiversity. Nature, v. 405, p. 234 -242, 2000.

DRUMMOND, J. A.; FRANCO, J. L. de A. \& NINIS, A. B. O Estado das Áreas Protegidas do Brasil. Brasília, 2006. Disponível em www.unbcds.pro.br/ conteudo_arquivo/150607_2F62A6.pdf. Acessado em: 09/12/2007.

FATMA - Fundação do Meio Ambiente de Santa Catarina. Plano de Manejo do Parque Estadual das Araucárias, 2004.

FATMA - Fundação do Meio Ambiente de Santa Catarina. Plano de Manejo do Parque Estadual Fritz Plaumann (PEFP), 2005.

FATMA - Fundação do Meio Ambiente de Santa Catarina. Núcleo de Unidades de Conservação. Disponível em http://www.fatma.sc.gov.br. Consultado em 05/12/2007 .

FERREIRA, L. V.; VENTICINQUE, E. A.; ALMEIDA, S. S. O desmatamento na Amazônia e a importância das áreas protegidas. Estudos avançados, v.19, n 53, p. 1-10, 2005.

HORUS - Instituto Hórus de Conservação e Desenvolvimento Ambiental - Espécies Exóticas Invasoras: Fichas técnicas. Disponível em http://:// www.institutohorus.org.br. Consultado em 08/12/ 2007.

IBAMA - Instituto Brasileiro de Meio Ambiente e dos Recursos Naturais Renováveis. Disponível em http://www.ibama.gov.br. Consultado em 11/12/2007. IBGE - Instituto Brasileiro de Geografia e Estatística. Disponível em http://www.ibge.gov.br. Consultado em 12/12/2007.

KLEIN, 1978. In: Plano de Manejo do Parque

Estadual das Araucárias. FATMA, 2004.

LEWINSOHN, T. M. \& PRADO, P. I. Quantas espécies há no Brasil? Megadiversidade, vol. 1, no 1, p. 
36-42, 2005.

MP SC - Ministério Público de Santa Catarina. Assessoria de Comunicação do MPF/SC. Disponível em http://www.mp.sc.gov.br/portal/site/portal. Consultado em 08/12/2007.

PROCHNOW, M. (org.) Matas Legais - Planejando Propriedades e Paisagens, $1^{\mathrm{a}} \mathrm{Ed}$, Rio do Sul, SC, 2008.

REITZ, R.; KLEIN, R.M.; REIS, A. Projeto Madeira de Santa Catarina. 320 p, 1978.

RYLANDS, A. B. \& BRANDON, K. Unidades de conservação brasileiras. Megadiversidade, vol.1, $\mathrm{N}^{\mathrm{o}}$ 1, 2005.

SDM - Secretaria de Estado do Desenvolvimento Urbano e Meio Ambiente. Bacias hidrográficas de Santa Catarina: diagnóstico geral. Florianópolis, 1997.

\section{Notas}

${ }^{1}$ Uma série de documentos informativos, assim como o Plano de Manejo do PEA foram gerados com recursos da Compensação Ambiental da Usina Hidrelétrica de Quebra Queixo. Esses documentos estão acessíveis pelo sitio virtual da FATMA.

${ }^{2}$ As unidades de uso sustentável visam compatibilizar a conservação da natureza com o uso sustentável dos recursos naturais, permitindo a explora;cão e o aproveitamento econômico direto desde que aconteça de forma planejada e regulamentada (BRASIL, 2007). 


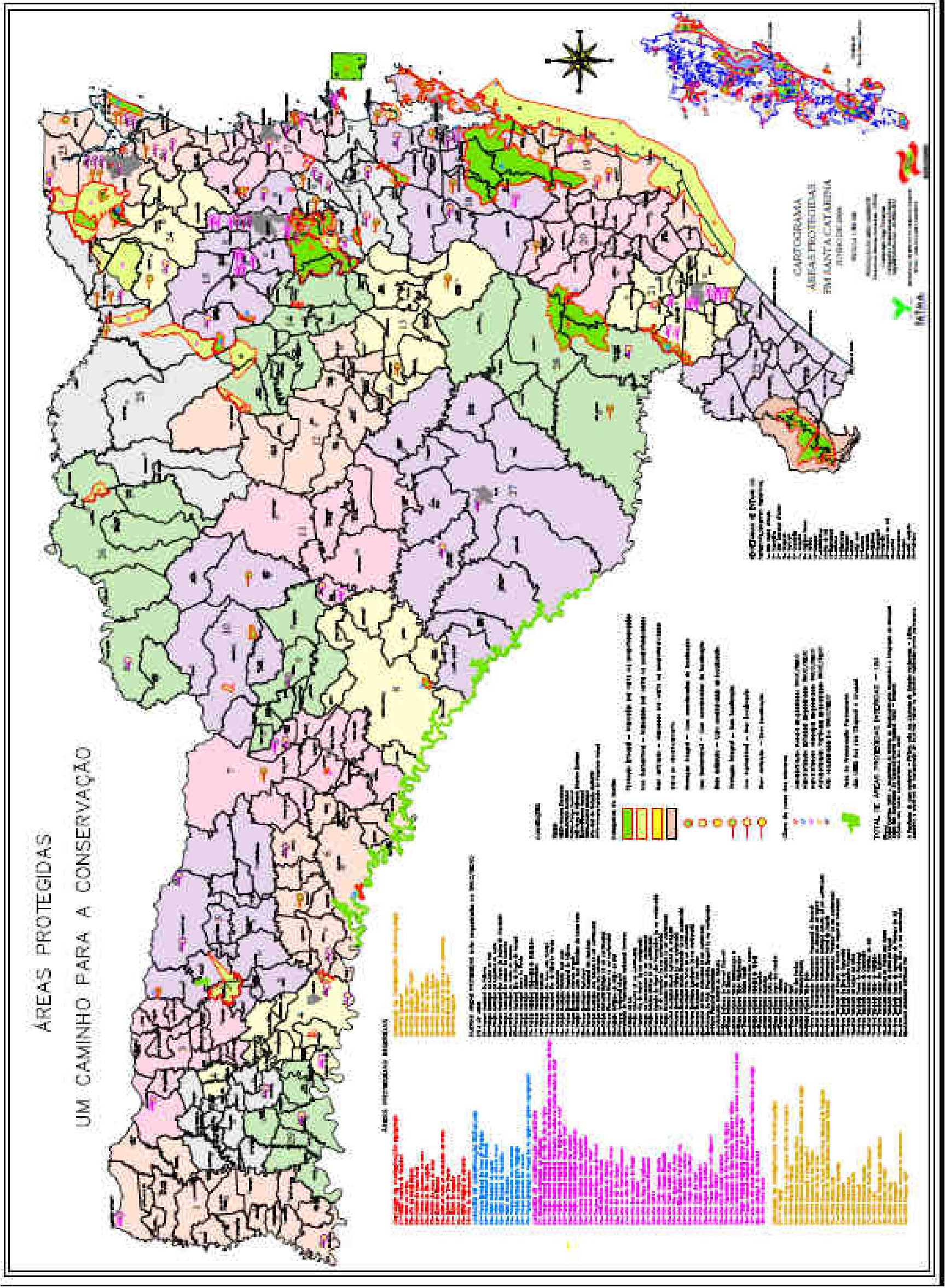


